\title{
Formation of Hexavalent Chromium through an Ash
}

\section{Drying Process}

\author{
Masaaki Takahashi ${ }^{*}$ and Yukimasa Takemoto \\ Faculty of Environmental and Information Science, Yokkaichi University, Yokkaichi 512-8512, Japan
}

\begin{abstract}
Hexavalent Chromium $\left(\mathrm{Cr}^{6+}\right)$ is one of the hazardous compounds, and a lot of pollution has been found around the waste dumpling site or in the yard of chemical factory. In order to find the cause of the $\mathrm{Cr}^{6+}$ formation, chemical change of Chromium was investigated. In the incinerated ash, $\mathrm{Cr}^{6+}$ was formed by drying treatment in alkali condition. However, no formation of $\mathrm{Cr}^{6+}$ was found in normal soil, this difference is depends on the state of Chromium component in the waste.
\end{abstract}

Key words: Ash, drying, hexavalent chromium, formation.

\section{Introduction}

Hexavalent Chromium $\left(\mathrm{Cr}^{6+}\right)$ is one of the hazardous compound, and some pollution has been found around in Japan especially in the waste dumpling site or in the yard of old chemical factory, causing a lot of soil contamination [1-4]. Almost all of these $\mathrm{Cr}^{6+}$ problems are considered as a pollution by-product of many chemical process. Especially leaching from cement construction material are often reported [5].

Recently, $\mathrm{Cr}^{6+}$ pollution from dumping area of "Ferro-silt" was reported. "Ferro-silt" is a commercial name which is formed by neutralization of the titan acidic extract. One of the causes of this pollution is $\left(\mathrm{Cr}^{6+}\right)$ 's formation in drying process is considered [6].

Usually, $200 \mathrm{mg} / \mathrm{kg}$ to $300 \mathrm{mg} / \mathrm{kg}$ of Chromium is contained in the ash or soil. $\mathrm{C}^{6+}$ is considered, that it is formed in heat treatment from $500{ }^{\circ} \mathrm{C}$ to $700{ }^{\circ} \mathrm{C}[7,8]$, however, $\mathrm{Cr}^{6+}$ formation in low Temperature was not reported. In order to find a cause of the $\mathrm{Cr}^{6+}$ pollution in landfill site, we investigated a $\mathrm{Cr}^{6+}$ formation in drying treatment at low Temperature (room Temp. to $\left.150^{\circ} \mathrm{C}\right)[9,10]$.

\footnotetext{
*Corresponding author: Masaaki Takahashi, researcher, research field: environmental technology, E-mail : machaaki@amigo.ne.jp.
}

\section{Methods}

\subsection{Materials}

In our experiment, mountain soil and incinerated ash were used. The mountain soil is an silty clay which is dug out for construction sands around the mine near the Suzuka mountain chain located in west side of Yokkaichi. Incinerated ash of sewage sludge is discharged from the sewage treatment plant in Yokkaichi city, which is incinerated in the fluid type furnace at $850{ }^{\circ} \mathrm{C}$. Chemical compositions of the ash and mountain soil are listed in Table 1. Chromium contents in the incineration ash and mountain soil are about $800 \mathrm{mg} / \mathrm{kg}$ and $400 \mathrm{mg} / \mathrm{kg}$ (as $\mathrm{Cr}_{2} \mathrm{O}_{3}$ ) respectively.

\subsection{Experimental Methods}

$20 \mathrm{~g}$ of ash or mountain soil was put in the evaporation dish, $20 \mathrm{ml}$ of aq. $\mathrm{NaOH}$ solution (containing $\mathrm{NaOH} 10 \mathrm{~g}$ ) was added, and dried at some Temp. (room Temp. to $150{ }^{\circ} \mathrm{C}$ ) in a heating chamber respectively.

In order to confirm the hexavalent chromium formation, treated samples (ash and soil) were transferred into the glass beaker, and $200 \mathrm{ml}$ of water (solid/liquid 1:10) was added for elution test, stirred 60 min using magnetic stirrer. After stirring, $60 \mathrm{~min}$ of 


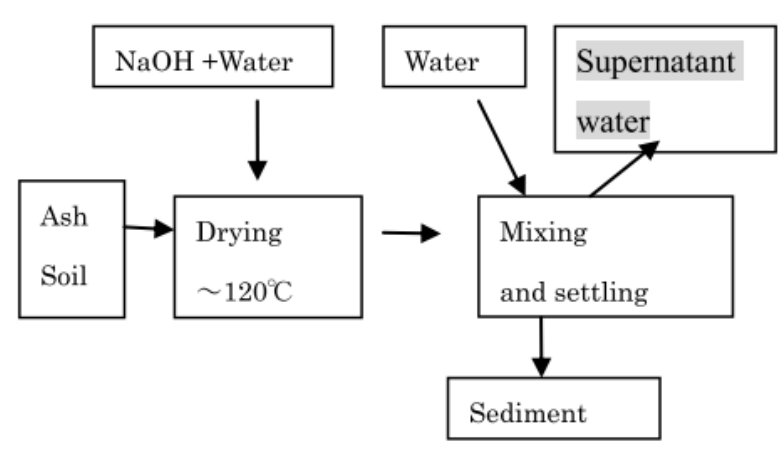

Fig. 1 Experimental procedure.

Table 1 Composition of the test material.

\begin{tabular}{lll}
\hline Compositions & Sewage ash (\%) & Mountain soild (\%) \\
\hline $\mathrm{SiO}_{2}$ & 26 & 62 \\
$\mathrm{Al}_{2} \mathrm{O}_{3}$ & 12 & 17 \\
$\mathrm{CaO}$ & 14 & 2.5 \\
$\mathrm{Fe}_{2} \mathrm{O}_{3}$ & 17 & 8.1 \\
$\mathrm{P}_{2} \mathrm{O}_{5}$ & 19 & $<0.01$ \\
$\mathrm{Cr}_{2} \mathrm{O}_{3}$ & 0.08 & 0.04 \\
Others & 12 & 10 \\
\hline
\end{tabular}

Table $2 \mathrm{Cr}^{6+}$ concentration in the supernatant water.

\begin{tabular}{llll}
\hline \multicolumn{2}{c}{ Incinerated ash (mg/L) } & \multicolumn{2}{c}{ Mountain soil } \\
\hline Non-treated & Treated & Non-treated & Treated \\
\hline ND & 0.42 & ND & ND \\
\hline
\end{tabular}

ND: Non detected.

sedimentation was carried out, almost all of the ash or soil was precipitated and supernatant water became transparent. $50 \mathrm{ml}$ of supernatant water was taken out from the beaker. The supernatant water was in strong alkali condition, in order to meet with analysis, supernatant water was adjusted $\mathrm{pH}<2$ by addition of dil. $\mathrm{H}_{2} \mathrm{SO}_{4}$ (about $30 \%$ ), and hexavalent chromium was measured by diphenylcarbazide absorption photometry.

\section{Results and Discussion}

In order to confirm $\left(\mathrm{Cr}^{6+}\right)$ 's formation, ash and soil were mixed with $\mathrm{NaOH}$ aq. solution, and dried at 105 ${ }^{\circ} \mathrm{C}$, $4 \mathrm{~h}$ as mentioned before, and $\mathrm{Cr}^{6+}$ concentration of the supernatant water is shown in Table 2. $0.37 \mathrm{mg} / \mathrm{L}$ of $\mathrm{Cr}^{6+}$ was detected in supernatant water of dried ash, contrary, $\mathrm{Cr}^{6+}$ was not detected in the water of non-treated ash. In the case of mountain soil, $\mathrm{Cr}^{6+}$ was not detected in the treated soil and the non-treated one. These difference of the $\left(\mathrm{Cr}^{6+}\right)$ 's formation in the ash and mountain soil is considered as not dependent on the chromium concentration but the state of the chromium compound in the material. In order to identify the conditions which can form $\mathrm{Cr}^{6+}$, the relation between the concentrations of $\mathrm{Cr}^{6+}$ to the amount of alkali added to the ash, and drying Temp. was also investigated. $\mathrm{Cr}^{6+}$ formations was found in the addition rate more than $5 \mathrm{~g} \mathrm{NaOH}$ (Fig. 2). At room Temp., $\mathrm{Cr}^{6+}$ was not found, and in high drying Temp. (over $100{ }^{\circ} \mathrm{C}$ ), $\mathrm{Cr}^{6+}$ was found as shown in Fig. 3. With the relation of the $\mathrm{Cr}^{6+}$ concentration and drying time, high $\mathrm{Cr}^{6+}$ was found in a long drying time (Fig. 4).

These results showed the formation of $\mathrm{Cr}^{6+}$ in drying treatment, however, $\left(\mathrm{Cr}^{6+}\right)$ 's formation by heating without drying should also be considered. In order to confirm this concern, $\left(\mathrm{Cr}^{6+}\right)$ 's formation in wet or dry conditions was investigated.

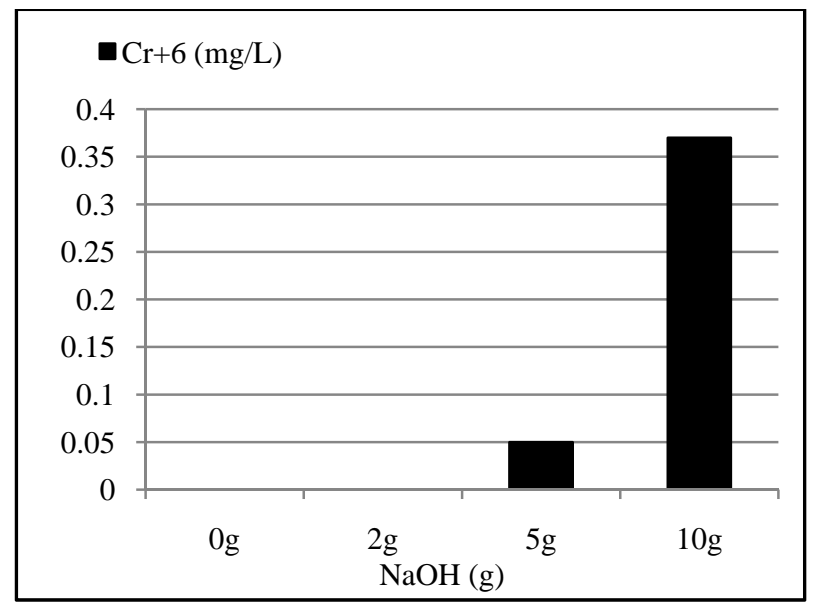

Fig. 2 Relation of $\mathrm{Cr}^{6+}$ and $\mathrm{NaOH}$ addition rate.

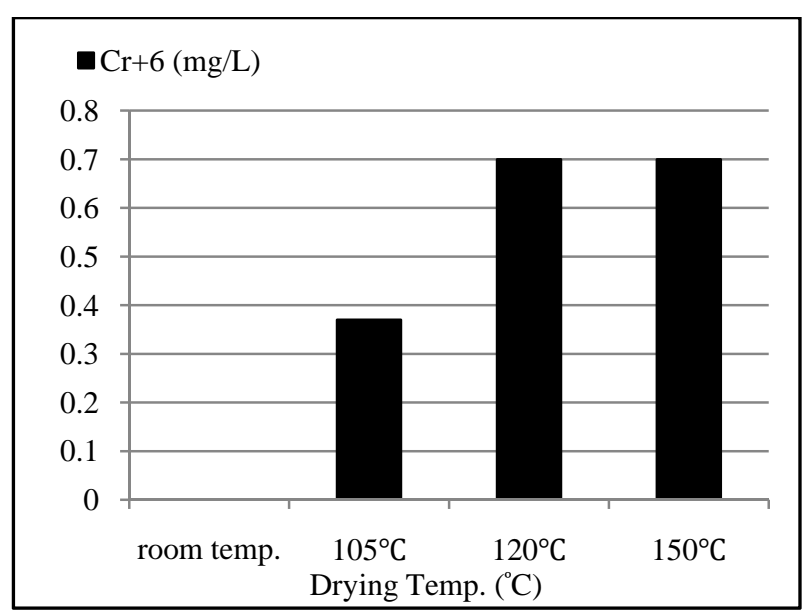

Fig. 3 Relation of $\mathrm{Cr}^{6+}$ and drying Temp. 


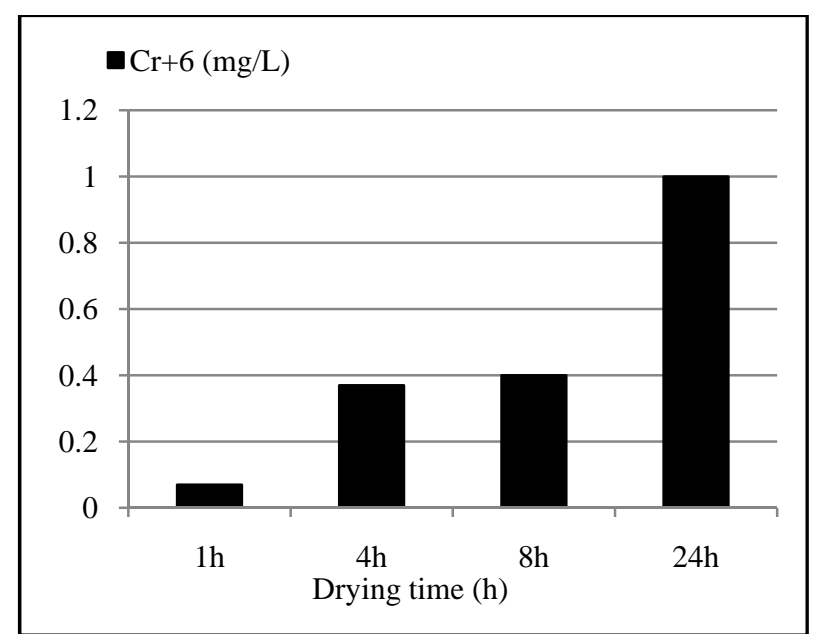

Fig. 4 Relation of $\mathrm{Cr}^{6+}$ and drying time.

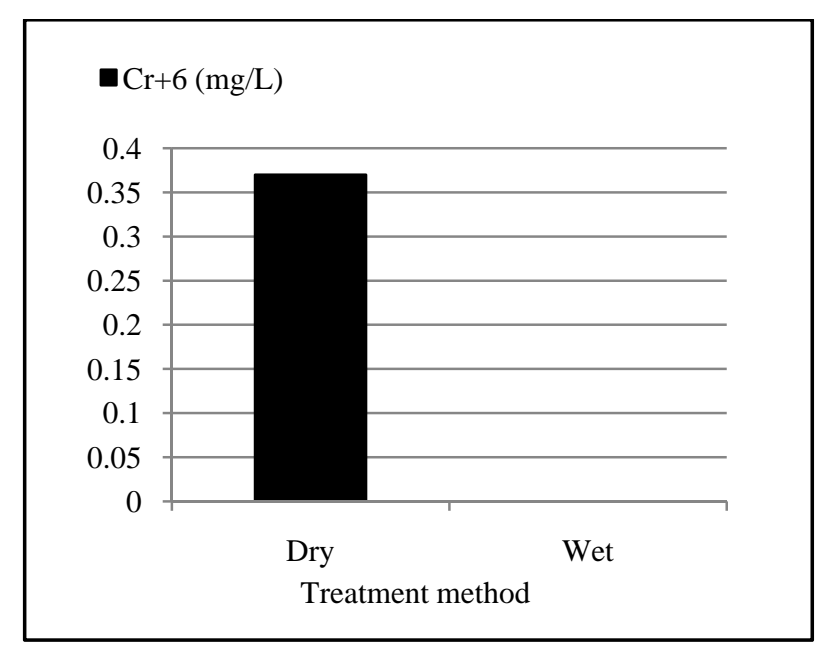

Fig. $5 \mathrm{Cr}^{6+}$ concentration drying.

$20 \mathrm{~g}$ of ash was mixed with $\mathrm{NaOH}$ aq. solution (containing $\mathrm{NaOH} 10 \mathrm{~g}$ ), and put into the two vessel, one was opened, and another was closed to prevent drying, and heated at $105{ }^{\circ} \mathrm{C}$, for $24 \mathrm{~h}$. $\mathrm{Cr}^{6+}$ concentrations in the two vessels were analyzed respectively. $\mathrm{Cr}^{6+}$ was found in the ash of opened vessel (Fig. 5). This result showed $\mathrm{Cr}^{6+}$ is formed in a dry condition at this Temperature.

\section{Conclusions}

In order to confirm $\left(\mathrm{Cr}^{6+}\right)$ 's formation by drying treatment, incinerated ash of sewage sludge and mountain soil were dried in alkali condition. $\mathrm{Cr}^{6+}$ was found in dried ash. Contrary, elution of $\mathrm{Cr}^{6+}$ was not found from mountain soil, and the result depends on the state of $\mathrm{Cr}$ compound in materials.

Recently, recycle technology of incinerated ash or sludge is going on, however, formation of $\mathrm{Cr}^{6+}$ in recycle processes will be considered as an important matter.

\section{References}

[1] Tokyo Metropolitan

Government, http://www.kankyo.metro.tokyo.jp/chemical/soil/informat ion/cr6.html.

[2] Nikkan SPA http://www.nikkan_spa.jp/2109.

[3] Yamanaka, R., Oomori, M., Nishimori, K. and Senba, S. 2008. "The Ground Water Pollution by Hexavalent Chromium and the Counter Measure in Kochi Prefecture.” Annual Report of Kochi Prefectural Environmental Research Center. No. 25: 17-31.

[4] Hori, M., Shozugawa, K. and Matsuo, M. 2014. "Evaluation of Cr(VI) Pollution Caused by Dumped Chromium Slag at the Urban Park in Tokyo.” Photon Factory Activity Report.

[5] Morita, H. 2008. "Feature on Hexavalent Chromium Leaching from Cement Reformed Soil.” JCM Monthly Report 17 (5): No. 3.

[6] "Investigation on Hexavalent Chromium pollution from Ferro-silt.” Mie Prefectural Government, http;//www.eco.pref.mie.lg.jp/cycle/100080/fersrt/doc-ho ukoku-h171215/hokoku03pdf.

[7] Sogawa, K. andYmamura, S. 2009. "Surveillance Study to Recycle Wood Pellet Combustion Ash Properly and Safely”, Annual Report of Kochi Prefectural Environmental Research Center 26: 17-23.

[8] Sonoda, T., Hotta, M., Yonekura, I., Miura, M. and Saito, H. 2006. "Control Technology of Metal Corrosion Caused by Wood Pellet Ash", Journal of Local Independent Administrative Agency Iwate Industrial Research Institute Jun 13: 112-5.

[9] Miyawaki, K., Osako, M. and Kida, A. 2006. “Hexavalent Chromium Leaching Characterization from Recycled Material on Dry-Wet Repetition Test.” In Proceedings of WASCON. 169-75.

[10] Masaaki, T. 2006. "Hexavalent Chromium Formation in the Incinerated Ash by Drying Treatment." In Proceedings of the $17^{\text {th }}$ annual conference of the Japansociety of waste management experts. 1098-100. 